ERC Working Papers in Economics 14/03

May/ 2014

\title{
Entry to Foreign Markets and Productivity: Evidence from a Matched Sample of Turkish Manufacturing Firms
}

\author{
Başak Dalgıç \\ Department of Public Finance, Hacettepe University \\ Ankara, TURKEY \\ E-mail: basakcakar@hacettepe.edu.tr
}

\author{
Burcu Fazlığ lu \\ Department of International Entrepreneurship, TOBB ETU University \\ Ankara, TURKEY \\ E-mail: bfazlioglu@etu.edu.tr \\ Deniz Karaoğlan \\ Department of Economics, Middle East Technical University, \\ Ankara, TURKEY \\ E-mail: kadeniz@metu.edu.tr \\ Phone: + (90) 3122103069
}




\title{
Entry to Foreign Markets and Productivity: Evidence from a
}

\section{Matched Sample of Turkish Manufacturing Firms}

Başak Dalgıç $^{1}$
Burcu Fazlığ $\operatorname{lu}^{2}$

June 2014
Deniz Karaoğlan ${ }^{3}$

\begin{abstract}
We examine the effects of international trading activities of firms on creating productivity gains in Turkey by using a recent firm level dataset over the period 2003-2010. We establish treatment models and investigate the productivity improvements of firms through trade by using Propensity Score Matching (PSM) techniques along with Differencein-Difference (DID) estimates. Three different groups of treatment are constructed: (i) firms that involve only in importing activities, (ii) firms that involve only in exporting activities, (iii) firms that involve in both exporting and importing activities. The results of the study suggest that both exporting and importing have positive significant effects on total factor productivity (TFP) and labor productivity (LP) of firms. Importing is found to have a greater impact on productivity of firms compared to exporting. Further, two-way trade is found to have more significant effects than those of one-way trade on firm productivity. Finally, our results indicate that international trade has greater impact on LP rather than TFP of firms.
\end{abstract}

Keywords: Productivity, Imports, Exports, Propensity Score Matching

JEL Classifications: F10, D21, D24, C21, C2

\footnotetext{
${ }^{1}$ Department of Public Finance, Hacettepe University, Turkey. e-mail: basakcakar@hacettepe.edu.tr

${ }^{2}$ Department of International Entrepreneurship, TOBB ETU University, Turkey. e-mail: bfazlioglu @etu.edu.tr

${ }^{3}$ Department of Economics, Middle East Technical University, Turkey. e-mail: kadeniz@metu.edu.tr
} 


\section{Introduction and Background Literature}

Productivity growth has been the main source of economic growth. In developed regions of the world while improvements in productivity is essential for sustainable growth, in emerging and least developed countries it comes as a much more important concept to catch up with the developed economies. Related theoretical and empirical literature at macro level, put forward that international linkages provide channels for economic units to improve their productivity (Grossman and Helpman, 1991; Rivera-Batiz and Romer, 1991; Coe and Helpman, 1995). Accordingly, the interaction of economies with outside world will provide internalization of the foreign technological knowledge at the frontier. This process will particularly accelerate productivity growth of emerging economies via importing new and more variety of intermediate and capital goods in their production processes. Productivity gains take place through other forms of international activities such as serving foreign markets through exporting, and setting a subsidiary as well as sourcing from foreign markets through importing.

With the emergence of new new trade theory, the interest for the link between international trade and productivity has been re-established as the focus has been switched from the investigation of macro level agents to micro players of trade. While the microeconometrics of firms' involvement in international trade is pioneered by Bernard and Jensen (1999), Aw and Hwang (1995) and Roberts and Tybout (1997), the theoretical framework to the discussion is provided by the seminal works of Melitz (2003) and Bernard et al. (2006). With the availability of firm level datasets new stylized facts has been shown, suggesting that internationalized firms show superior performance to the firms who serve only to the domestic markets ${ }^{4}$. Two different theoretical interpretations have been proposed to explain

\footnotetext{
${ }^{4}$ See Greenaway and Kneller (2007), Wagner (2007) and Wagner (2012) for surveys of the regarding literature..
} 
this premia: the self-selection hypothesis and post-entry mechanisms. Self-selection hypothesis suggests that due to the existence of sunk costs and different productivity levels within the same industry, only the most productive firms could self select into export markets. Post entry mechanisms provide an alternative but not mutually exclusive explanation of superior performance of exporters. Particularly, according to learning by exporting hypothesis firms can become more efficient after they begin exporting through learning or economies of scale effects via interaction with the foreign clients and being exposed to intensive competition in the international markets. In terms of importing and productivity nexus, the literature on import premia also focuses on the self-selection and post-entry mechanisms. Self selection hypothesis builds on the observation that due to fixed costs of importing, only the firms above some productivity threshold could import ${ }^{5}$ (Vogel and Wagner, 2010; Smeets and Warzynski, 2013). Regarding the post entry mechanisms of importing, theoretical models (Eaton and Kortum, 2001; Acharya and Keller, 2009) emphasize a strong learning effect through importing intermediate and capital goods via international knowledge spillover, variety effect and a quality effect.

The aim of this paper is to investigate the post entry mechanisms namely, learning by exporting and learning by importing of firms in Turkey which stands as a low-middle income country. Particularly, we test whether exporting and importing leads to productivity gains for Turkish manufacturing firms over the period 2003-2010. While doing so we distinguish between one way and two way trading activities of firms. The case of Turkey is interesting since it is an emerging economy whose growth is mainly driven by trade. Our period choice makes this study even more appealing since Turkey has particularly experienced a trade boom after 2002 and undergone a structural transformation in terms of its production and trade

\footnotetext{
${ }^{5}$ Similar to the self selection mechanism in the exporting case, these costs are referred as sunk costs (search cost for foreign suppliers, inspection of goods, negotiation, contract formulation, learning and acquisition of customs procedures).
} 
patterns over this period ${ }^{6}$. We apply the Propensity Score Matching (PSM) algorithm together with Differences-in-Differences (DID) methodology to the largest and most recent firm level panel available for Turkish manufacturing industry. By making use of the PSM-DID methodology our objective is to accurately identify the productivity gains that arise from learning externalities associated to international trade controlling for self-selection of firms into trade.

PSM methodology provides us a matched sample of firms which have similar characteristics independent of their choice of trading activity. In this manner, we rely on firm specific characteristics and some sectoral indicators to produce a score representing the firms' propensity to improve productivity (Rosenbaum and Rubin, 1983). This enables us to have estimates of productivity differences that are purified from the selection bias which is observed in non-experimental data (Dehejia and Wahba, 2002). Nevertheless, PSM methodology does not eliminate all the biases, especially the biases from time invariant unobservables. To remove these biases, we calculate the DID estimators after PSM and decide whether international trade activities improve the firm's productivity over time. By implementing the PSM methodology with DID estimators, the quality of our results is improved as Blundell and Costa-Dias (2000) suggest.

Early studies claim that exporting may lead to productivity gains in two ways (Clerides et al, 1998; Castellani, 2002). First, the linkage with buyers and suppliers is an important source of learning. In addition to the possibility that exporting firms might take technical assistance from their buyers, it is likely for buyers to specify products with higher quality as well. Yet, with the emergence of the literature on firm heterogeneity in international trade, exporting channel has received much more attention within the context of post entry

\footnotetext{
${ }^{6}$ The choice of manufacturing industry is telling in terms of reflecting the production and its development stages in Turkey. For instance, over the period 2000-2010 the share of Turkish manufacturing industry in GDP is $23.5 \%$ on average. While manufacturing industry constitutes $18.5 \%$ of overall employment in Turkey, it generates $93.5 \%$ of total export volume in the underlined period.
} 
mechanisms of trade. In the firm heterogeneity literature tackling the post entry mechanisms, scholars explain the performance increase of exporting firms by learning by exporting hypothesis (see among others: Baldwin and Gu, 2004; Girma et al., 2004; Van Biesebroeck, 2003; Isgut and Fernandes, 2007; De Loecker, 2007; Serti and Tomasi, 2008). They suggest that exporting improves firm productivity through interaction with foreign buyers and facing competition in the foreign markets.

Productivity improvements which are mediated by importing activities of firms may arise through both horizontal and vertical linkages (Eaton and Kortum, 2001; Acharya and Keller, 2009). Theoretical models stress a strong causality from importing new varieties of intermediate and capital goods to productivity. Moreover, they emphasize that a quality effect emerges by utilizing better quality of inputs than domestic ones. On the empirical side, many scholars such as Halpern et al. (2005) (for Hungary), Kasahara and Lapham (2008) (for Chile), Bas and Strauss-Kahn (2010) (for France), Forlani (2010) (for Ireland), Yasar and Paul (2008) (for Turkey) provides evidence for learning by importing effect.

Very limited empirical evidence is presented for Turkey on trade and productivity linkage. Yasar and Rejesus (2005) employ PSM techniques to test for the learning by exporting effect on firm performance. They find out that learning by exporting is at work, yet their analysis includes only a small sample of sectors for 1990-1996. Using a different source of dataset for the period 1989-2003 with only 4498 firms and utilizing PSM techniques, Aldan and Günay (2008) also suggest starting to export further increases labor productivity. Yasar and Paul (2008) examine the three alternative channels (foreign direct investment, importing, exporting) of foreign technology transfer employing PSM techniques for Turkish manufacturing plants. Although they find evidence for technology transfer through exporting and foreign direct investment channels, they suggest that their results turn to be ambiguous at 


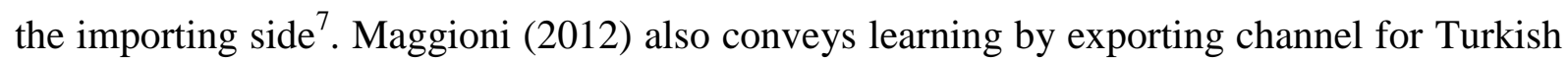
manufacturing firms over 1990-2001 period using PSM methodology.

Our study complements above mentioned literature on Turkey by extending the analyses to a recent time horizon 2003-2010. Regarding the post entry mechanisms led by firms' interaction with foreign markets, this time period is being considered for the first time for Turkish manufacturing industry. Similar to Yasar and Rejesus (2005), Aldan and Günay (2008) and Maggioni (2012) we find the export channel quite significant for labor productivity. Additionally, in contrast with Yasar and Paul (2008) we find robust evidence for the positive impact of importing activity on firm productivity. The reason that our result differs from Yasar and Paul (2008) may be driven by two factors. One could simply stem from the fact that coverage of the samples is different in terms of both sectoral coverage and time horizon. On the other hand, this result may reflect the transformation process experienced by Turkey after 2002. Compared to Yasar and Paul's (2008) sample over 19901996, in the post 2002 period, Turkish manufacturing industry might have exceeded a certain threshold level of technological knowledge stock in order to absorb and internalize the knowledge available in international environment. Apart from all above, our results suggest that importing activity has a greater impact on firm productivity relative to exporting. Furthermore, both importing and exporting have more significant effects on labor productivity (LP) of the firms compared to total factor productivity (TFP).

It can be argued that only one of the trading activities (importing or exporting) might have a significant effect on productivity. Unless the treatment is decomposed into involvement in one way (i.e. only-importing/only-exporting) and two-way trading, one can observe significant positive effects for both kind of trading activities since importing and exporting might be correlated within a firm. The existing literature on Turkey does not

\footnotetext{
${ }^{7}$ Similar to their previous study, their dataset covers a sample of firms from three manufacturing sectors over the period 1990-1996.
} 
differentiate between one way and two way traders in investigating the productivity gains from international trade. We contribute to the regarding literature distinguishing between the effects of one way trading activities and two-way trading activities on firm productivity for the first time. Accordingly, we detect all the different effects of exporting vs. importing by forming an additional treatment group ${ }^{8}$ which includes firms that are formerly only importers (only exporters) and become two-way traders afterwards, whereas our control group includes the firms which remain to be only importers (only exporters). We find that two-way trade has more significant effects than those of one-way trade on firm productivity. Moreover, the comparison of the effects of two-way trading and one-way trading on firm productivity support the result that the impact of importing on productivity is greater than that of exporting.

The remainder of this paper is organized as follows: Section two introduces the data and methodology. Section three presents the results of our empirical investigation. Section four discusses the robustness checks. Section five concludes.

\section{Data and Empirical Investigation}

In this study we utilize a recent Turkish firm level panel which is based on two different sources of data collected by Turkish State Institute of Statistics (TURKSTAT) ${ }^{9}$. We combine Annual Industry and Service Statistics ${ }^{10}$ with Annual Trade Statistics ${ }^{11}$. For this study we

\footnotetext{
${ }^{8}$ Our initial treatment group consists of firms that are formerly non-traders and starts one way trading afterwards, whereas our control group includes the firms which remain to be the firms that never import or export.

9 These datasets are available under a confidential agreement by which all the elaborations can only be conducted at the Microdata Research Centre of TurkStat under the respect of the law on the statistic secret and the personal data protection.

${ }^{10}$ The Annual Industry and Service Statistics is a census of firms with more than 20 employees while it is a representative survey for firms with less than 20 employees. In Annual Industry and Service Statistics dataset, firms are classified according to their main activity, as identified by Eurostat's NACE Rev. 1.1 standard codes for sectoral classification.
} 
selecthe whole population of private Turkish manufacturing firms with 20 employees or more $^{12}$. Our unbalanced panel covers longitudinal data of 17700 firms on average over the period $2003-2010^{13}$.

In order to assess firm level productivity we use two different measures: labor productivity (LP) and total factor productivity (TFP). We calculate LP as value added (gross output net of intermediate inputs) per employee. Our TFP measure is calculated using the Levinsohn and Petrin's (2003) semi-parametric approach. OLS estimation of a Cobb-Douglas production functions yields some methodological problems. Griliches and Mareisse (1995) emphasize that input demands of the firms are correlated with unobserved productivity shocks i.e. profit-maximizing firms immediately adjust their inputs each time whenever they observe these productivity shocks. Thus, treating inputs as exogenous variables can create simultaneity bias in the OLS estimation of production functions since the unobserved shocks will be captured in the error term. Regarding the OLS estimation of the production function, another problem that may arise is the selection bias as capital stock responds to productivity shocks with a lag. Firms with larger amounts of capital stock would expect higher future returns for any given productivity level and, hence, they will continue to operate even if they observe low levels of productivity for the next period (Olley and Pakes, 1996). However, firms with lower amounts of capital stock may not be able to remain in the market in similar conditions. While several theoretical models predict that the growth and exit patterns of firms

\footnotetext{
${ }^{11}$ This firm level data is sourced from customs declarations. The import and export flows are collected for the whole universe of the importers and exporters of goods at 12-digit GTIP classification.

${ }^{12}$ Firms with 20 and more than 20 employees account for a large share of Turkish manufacturing industry. For example, they constitute $87 \%$ of production in value and $75 \%$ of employment in 2009. It shows a similar pattern in the previous and following years. Moreover in the presence of sunk costs since trade activity is mostly performed by large firms our selection does not create biased results.

${ }^{13}$ The original sample size in the merged dataset was slightly larger but we applied a cleaning procedure which is largely inspired by Hall and Mairesse (1995). We threw out the abnormal observations (zero / negative) for the main variables such as output, intermediate inputs, labor cost etc.). Then, we excluded observations where main variables and ratios (e.g. employee, value added per employee, capital per employee) displays extraordinary jumps and drops over one year. Finally, we excluded firms in NACE sectors 16 (Manufacture of tobacco products), 23 (Manufacture of coke, refined petroleum products and nuclear fuel), 30 (Manufacture of office, accounting and computing machinery), 37 (Recycling) since they include small number of firms.
} 
are motivated to a large extent by productivity differences, conditional on the existence in the data, if productivity level is known by firms prior to their exit, a correlation between productivity and capital stock would exist. Thus a negative correlation between the disturbance term and capital stock is expected in OLS estimation i.e the resulting capital coefficient is an underestimate of the true coefficient.

To overcome to these biases, several methodologies have been proposed in the literature. Among them Olley and Pakes (1996) and Levinsohn and Petrin (2003) have been successful in reducing these methodological problems by offering a semiparametric estimator. Olley and Pakes (1996) suggest to proxy productivity shocks with investment decision of the firms and therefore eliminate the relationship between productivity shocks and variable inputs. Moreover, they incorporate an exit-entry rule into the estimation procedure to overcome the selection bias. Alternatively, Levinsohn and Petrin (2003) suggest that investment cannot be monotonically increasing in productivity in datasets with a large number zero observations in investment. As deleting these zero observations would create loss in terms of efficiency Levinsohn and Petrin (2003) propose to use material inputs as a proxy into the estimation as material inputs are generally reported positively in firm level datasets. Since our dataset shows a similar pattern (a large number zero observations in investment series) we prefer to use Levinsohn and Petrin's (2003) methodology ${ }^{14}$ in estimating our TFP measure.

\footnotetext{
${ }^{14}$ Levinsohn and Petrin (2003) assumes the production technology to be Cobb-Douglas where the logarithm of firms' output is explained by the logarithm of the freely variable inputs-labor $\left(l_{i t}\right)$, material inputs $\left(m_{i t}\right)$, and energy input $\left(e_{i t}\right)$ - and the logarithm of the state variable-capital $\left(k_{i t}\right)$. Firms' output is proxied by gross revenue or value added. We use value added $\left(v_{i t}\right)$ as our dependent variable since, when output is used as the dependent variable, Levinsohn Petrin (2003) is not able to identify the coefficients for material inputs, energy, labor and capital due to the lack of variation in data (Arnold, 2005). Disaggregating the error term into productivity shocks known to the producer $\left(w_{i t}\right)$ and unobservable shocks $\left(\varepsilon_{i t}\right)$ the following production function is estimated: $\left(v_{i t}=\beta_{0}+\beta_{l} l_{i t}+\beta_{k} k_{i t}+w_{i t}+\varepsilon_{i t}\right.$ ) (eqn.1), where the $w_{i t}$ follows a first order Markov process. It is assumed that the demand for the material inputs is dependent on capital stock and known productivity shocks. Further, it is assumed that material inputs are monotinally increasing in productivity so that the inverse of the material input demand function $\left(h_{i t}\right)$ exists. Equation 1 can be re-written as $v_{i t}=\beta_{0}+\beta_{1} l_{i t}+\Phi_{i t}\left(k_{i t}, m_{i t}\right)+w_{i t}$ (eqn.2) where $\Phi_{i t}\left(k_{i t}, m_{i t}\right)=\beta_{0}+\beta_{k} k_{i t}+\mathrm{h}_{i t}\left(k_{i t}, m_{i t}\right)$ (eqn.3) Through estimating equation 2, by substituting a higher order polynomial for capital stock and material inputs in the inverse demand function $\left(h_{i t}\right)$, a consistent estimate for labor coefficient is obtained completing the first step of Levinsohn Petrin (2003) approach. The second stage of the routine identifies the coeffiecient of capital. Given the coefficient of labor, the coefficient of capital is defined as the solution to the following minimization problem: $\left.\left.\min \sum_{t} v_{i t}-{\widehat{\beta_{l}}}_{l i t}-\beta_{k} k_{i t}-E\left[w_{t t}\right]-w_{t t-1}\right]\right)^{2}$.
} 
Before estimating TFP, we calculate capital stock series of firms applying the perpetual inventory methodology using the investment series for machinery and equipment, building and structure, transportation equipment and computer and programming. Initial capital stock is calculated by assuming that the firms are at their balanced growth path and it is obtained by dividing the initial investment flow to the sum of depreciation rate and growth rate of output $^{15,16}$. For the firms that report zero investment at their initial year, it is assumed that they cannot be producing without capital. Therefore, initial capital stock is calculated at the year they report positive investment and this amount is iterated back to the beginning year by dividing capital stock each year. After calculating capital stock series for building and structure, machinery and equipment, transportation equipment, computer and programming, these series are aggregated to the total capital stock series of the firm.

In order to test the post entry effects of starting to trade in terms of productivity, we establish mainly two treatment models. In the first model, our treatment group consists of firms which does not import or export at time t-1, starts only-importing (only-exporting) at time $\mathrm{t}$ and continues only-importing (only-exporting) at time $\mathrm{t}+1$, whereas our control group includes firms that never import or export over the period in question (domestic firms). In this way, we have six cohorts each corresponds to a year between 2004 and 2009. In the second model, our treatment group consists of firms which were only-importing (only-exporting) at time $\mathrm{t}-1$ and starts to export (import) at time $\mathrm{t}$ and continues both importing and exporting at time $t+1$. Our control group covers the firms which remain to be only-importers (onlyexporters) over the analysis period. In other words, our treatment group includes two-way traders and our control group includes one-way traders. By establishing the second model, we

\footnotetext{
${ }^{15}$ Denoting the initial year of the firm with zero the initial capital stock is constructed as follows: $K_{1}=(1-\delta) K_{0}+I_{0}$ (eqn. 1$), \frac{K_{1}}{K_{0}}=(1-\delta)+\frac{I_{0}}{K_{0}}($ eqn. 2$)$.

Since firms are at their balanced growth path, the growth rate of capital is equal to the growth rate of output $(1+\mathrm{g})$. From equation 2 the initial capital stock can be obtained as follows: $K_{0}=I_{0} /(g+\delta)$.

${ }^{16}$ Following Y1lmaz and Özler (2005) depreciation rates of 5\%, 10\%, 20\% and 30\% are used for building and structure, machinery and equipment, transportation equipment, computer and programming respectively.
} 
aim to see whether two-way trade has more significant effects than those of one-way trade on firm productivity. In order to test the effect of trading on productivity of the firms we calculate the average treatment effects on the treated firms. The average treatment effect on the treated (ATT) is calculated as follows:

$$
A T T=E\left(Y_{i t}(1)-Y_{i t}(0) \mid D_{i}=1\right)=E\left(Y_{i t}(1) \mid D_{i}=1\right)-E\left(Y_{i t}(0) \mid D_{i}=1\right)
$$

For the first model, equation (1) shows the difference between the productivity level after the firm, which is formerly domestic $\left(D_{i}=1\right)$, starts to import (export) $\left(Y_{i t}(1) \mid D_{i}=1\right)$ and the potential productivity it would have if it would have never imported (exported) $\left(Y_{i t}(0) \mid D_{i}=1\right)$. Similarly, for the second model, equation (1) shows the difference between the outcome of the export (import) starter which is formerly an only importer (only exporter) $\left(Y_{i t}(1) \mid D_{i}=1\right)$ and the potential outcome it would have if it had stayed as an only importer (only exporter) $\left(\mathrm{Y}_{\mathrm{it}}(0) \mid \mathrm{D}_{\mathrm{i}}=1\right)$. The potential outcomes of both models are unknown. Nevertheless, we can calculate the outcome for control groups, which can be defined as $E\left(Y_{i t}(0) \mid D_{i}=0\right)$. Therefore, there can be a selection bias when ATT is calculated. The bias is defined as:

$$
B(A T T)=E\left(Y_{i t}(0) \mid D_{i}=1\right)-E\left(Y_{i t}(0) \mid D_{i}=0\right)
$$

The bias defined above will be zero, if treated and control groups have the same observable and non-observable characteristics. Dehajia and Wahba (2002) suggest comparing a treatment group with a non-experimental control group can give biased results because of problems such as self-selection or some systematic judgment by the researcher in selecting treatment units. To overcome the possible selection bias problem in our dataset, we will apply 
propensity score matching techniques (PSM) joint with difference- in difference methodology (DID) in order to test the impact of import (export) on productivity of the firm. We use DID estimator in order to improve the quality of our results as Blundell and Costa-Dias (2000) suggests.

In our analysis, our aim is to compare the firms whose observable characteristics are very similar. Thus these firms have very similar probabilities to receive treatment (similar propensity score), while one of them starts only exporting (only importing), and the other does not (for the second model one of them becomes two-way trader and the other remains to be only importer (only exporter)). After calculating the propensity scores, we will match the large group of non-treated units (non-exporters, non-importers) to treated ones (export (import) starters) (for the second model, the treated units are two-way traders and non-treated units are only importers (only exporters)). Next, we check whether the matching procedure is effective or not by comparing the means of the explanatory variables in both matched and unmatched samples. Lastly, we calculate ATT by nearest neighbor (NN) matching techniques on common support. The resulting ATT explains whether exporting, importing, two-way trading improve productivity of the firm. If ATT is found to be significant, we can conclude that to start exporting (importing) (for the second model, two-way trading) will benefit firms in terms of productivity.

Rosenbaum and Rubin (1983) define the propensity score as the conditional probability of receiving treatment (starting to export or import) given pre-treatment characteristics (for the second model the treatment is becoming a two-way trader),

$$
P_{i}\left(Z_{i}\right) \equiv \operatorname{Pr}\left(D_{i}=1 \mid Z_{i}\right)=E\left(D_{i} \mid Z_{i}\right)
$$


where $D_{i}=\{0,1\}$ is the indicator of treatment (to start importing (exporting) or, for the second model becoming a two-way trader) and, $Z_{i}$ is the vector of covariates on which the match is made. For our purposes, propensity score $\mathrm{P}_{\mathrm{i}}\left(\mathrm{Z}_{\mathrm{i}}\right)$ is computed from a probit regression in which the dependent variable is a binary variable which indicates whether the firm is an export (import) starter or not at time t (for the second model, whether the firm becomes a twoway trader). In the probit regressions, the vector of covariates consists of the logarithms of total factor productivity (TFP) or labor productivity (LP), logarithms of wage per employee (WAGE/L), logarithms of number of employees in the firm (EMPLOYEE), logarithms of capital intensity (CAPINT), unit labor cost (ULC), logarithms of sector output (SECO), year dummies and region dummies ${ }^{17}$. All of the independent variables are in their one period lagged value. We include the lagged values of the covariates since current values of these variables can also be affected by exporting (importing) behavior of the firms. Lastly, we include the higher powers of certain explanatory variables into the probit specifications in order to satisfy the balancing property of PSM algorithm following Dehajia and Wahba (2002).

After calculating the propensity scores, we look at the effect of exporting (importing) (for the second model the effect of two-way trade) on the productivity of the firm using the propensity score through Nearest Neighbor (NN) matching on common support. In NN matching an observation in control group is matched to an observation from treatment group based on the closest propensity score. We use matching with replacement so that one export

\footnotetext{
${ }^{17}$ In order to account for cost competitiveness of firms, we use unit labor cost (ULC) which takes both wage and productivity changes into account simultaneously. ULC is equal to the ratio of wages to labor productivity. To measure the scale of operation or size we utilize total number of employees. We define capital intensity of the firm as the ratio of the capital stock to the number of employees. To proxy skill intensity, we use wage per employee.
} 
(import) starter can be matched to more than one non-exporter (importer) (for the second model, two-way trader firm can be matched to more than one only importer (only exporter) $)^{18}$. Nevertheless, PSM does not overcome all the biases, especially the biases from time invariant unobservables. To remove these biases, we calculate the DID estimators after PSM. We simply call this estimate as PSM-DID estimate. In order to calculate PSM-DID estimate, firstly we take the difference of outcomes (TFP and LP) before and after the treatment (in the first case, the firm starts importing (exporting), in the second case the only importer (only exporter) firm becomes a two-way trader). Then, we apply the matching techniques where the outcome is the difference between the productivity levels before and after treatment. Finally, the resulting ATT gives the difference between average treatment effects of treated and nontreated groups in which time-invariant unobservables are eliminated. Hence, by applying the DID method we improve the quality of matching. We define the PSM-DID estimator as follows:

$\Delta^{P S M-D I D} A T T=E\left(Y_{i t}(1)-Y_{i t}(0) \mid D_{i}=1\right)-E\left(Y_{i t}(1)-Y_{i t}(0) \mid D_{i}=0\right)$

\section{Empirical Results}

We first establish the matched sample and check the quality of matching; that is we check whether the means of covariates is significantly different in matched and unmatched samples. Our results show that the matching procedure eliminates the inequality for means of covariates. Table 1 reports the significant differences between the means of covariates in the matched and unmatched sample. The results suggest that significant differences disappear in

\footnotetext{
${ }^{18}$ We calculate the propensity scores and average treatment effects in STATA by using the algorithm suggested by Becker and Ichino (2002). The standard errors provided in tables 2 through 5 are the analytical standard errors.
} 
the matched sample. For instance, the difference observed in the mean employment between exporters and non-exporters is 0.02 after matching while this difference is 0.18 for the unmatched sample (see Table 1). Furthermore, this difference in the means of the employment is also significant before matching while it turns to insignificant after matching with corresponding t-ratios of 0.55 and 10.98 respectively.

Since we show that matching procedure is efficient as it balances the mean of covariates for both treated and control groups, we can confidently move to estimating ATT. Recall that in our study, for the first model, ATT shows the impact of starting to export (import) on the productivity of formerly domestic firms, compared to their productivities in the absence of the exporting (importing) activity. In the second model, ATT shows the impact of becoming a two way trader on the productivity of the firms that are formerly one-way traders.

Next, we present the ATTs that result from NN matching and comment on the effects of international trade on firm productivity. In order to examine the effect of exporting and importing on productivity and to identify which kind of trading activity is more effective on the improvement of TFP/LP, we establish our control and treatment groups and apply the propensity score matching (PSM) techniques together with difference-in-difference (DID) estimators. Table 2 presents the PSM estimates of average treatment effects on treated (ATT) firms.

The results suggest that importing activities do statistically improve productivity of firms i.e. learning by importing effect is at work for Turkish manufacturing industry ${ }^{19}$. Specifically, while importing does not have a significant effect on TFP at time t the time when the firm starts to import), it significantly improves at time $t+1$ and $t+2$ by 36 percentage points. On the other hand, the expected positive impact of starting to import on LP of the firm is realized immediately (at time t). When the firm starts to import, the LP increases by 23

\footnotetext{
${ }^{19}$ Bas and Strauss-Kahn (2010) for France, Forlani (2010) for Ireland, Paul and Yasar (2009) for Turkey also provides empirical evidence for the learning by importing.
} 
percentage points at time $t$, and this percentage amounts to 28 at time $t+1$. At time $t+2$, we see that the positive impact of starting to import on LP pursues with a lower impact which is 24 percentage points. These results indicate that the positive effect of importing on the productivity of firms which are formerly domestic cannot be seen immediately for TFP whereas, LP is affected in the period the firm takes the treatment. Next, in terms of the effect of exporting the results indicate that for a domestic firm, starting to export does not significantly affect TFP whereas, starting to export increases LP by 23 percentage points two periods after the firm starts to export $(a t+2)$. In order to explain the possible rational behind the different findings on LP and TFP one should have a closer look at the differences in productivity measures. Labor productivity and total factor productivity-which measures productivity net of the contribution of capital-are subject to a debate in productivity research. Labor productivity is a direct estimate of productivity using readily available data on value added and labor inputs. Total factor productivity accounts for capital intensity yet capital stock is taken as an approximation of true capital stock of firms at any time period since initial capital stock and its growth rate are estimates. Both measures are well recognized in the literature and have significant implications. However, considering the fact that the quality of capital stock data improves over longer time periods, TFP is a more significant measure of productivity in the long run, whereas labor productivity is more reliable in the short run (Sargent and Rodriguez, 2000) $^{20}$. One can suggest that our findings of more significant effects on LP might be due to the fact that our study covers a short time horizon of five years.

Considering the findings regarding the domestic firms' starting to trade, we can also conclude that importing activity has more significant effects on firm productivity than that of exporting. i.e. learning by importing effect is more dominant than that of exporting for Turkish manufacturing firms. This result might be consistent with the view that while

\footnotetext{
${ }^{20}$ Sargent and Rodriguez (2000, p.43) state that "for periods of less than a decade labor productivity is a preferred measure, but for longer periods total factor productivity is superior".
} 
importing intermediate and capital goods transfer foreign knowledge accumulation directly to the domestic production processes (Grossman and Helpman, 1991; Rivera-Batiz and Romer, 1991), learning by exporting is not an automatic process and exporting does not necessarily improve firms (Albornoz and Ercolani, 2007; Wagner, 2012). Indeed, evidence regarding the learning-by-exporting hypothesis is somewhat mixed ${ }^{21}$ and most of the empirical works that confirm the learning by exporting hypothesis do so only under specific circumstances (Silva et al., 2012; Castellani, et al., 2010). For instance, Albornoz and Ercolani (2007) find that learning by exporting hypothesis is more relevant for exporting Argentinian firms which make intensive use of imported inputs. In our study, in fact, we find a more pronounced effect of exporting on firms' labor productivity which are formerly importing, than the effect of exporting on firms which are formerly domestic (see Tables 2 and 3). From another perspective, aggregating learning by exporting effects through industrial sectors instead of using only disaggregated levels might have offset these effects throughout the manufacturing sectors. For instance, using Turkish firm level data, Yasar et al. (2007) investigate the learning by exporting hypothesis for Turkish textile and apparel industry and motor and parts industry seperately and find stronger effects for the former one. They explain this finding by textile and apparel industry's being highly concentrated, more capital intensive and extensive in FDI than the motor and parts industry.

The comparison of two-way traders and one-way traders supports our finding on the fact that the impact of importing on productivity is greater than that of exporting. For instance, when the importer firms start to export, LP increases by 12 percentage points, 19 percentage points and 15 percentage points at time $t, t+1$ and $t+2$, respectively. Whereas, when the firms, which are formerly only exporters, start to import LP increases by 36 percentage points, 37

\footnotetext{
${ }^{21}$ Aw et al. (2000) studying firms from Taiwan and Korea finds no significant improvement of exporters relative to non-exporters. In another study for German firms Arnold and Hussinger (2005) find no significant productivity differences between exporting and non-exporting firms, neither in levels nor in growth rates.
} 
percentage points, 32 percentage points at time $t, t+1, t+2$ respectively. Finally, comparing the magnitude and significance of the average treatment effects from the two PSM estimates, two-way trading reveals to have more significant and greater effects on firms' productivity than those of one-way trading ${ }^{22}$.

Next, we employ PSM together with DID methodology in order to overcome the biases that result from time invariant unobservables. Table 3 presents the PSM-DID estimates. The outcome of the PSM-DID model represents the difference between the productivity levels of the firms before and after the treatment, that is the difference between the outcomes at time $\mathrm{t}-1$ and $\mathrm{t}+1$.The PSM-DID estimates support the findings obtained by PSM. We observe that LP of the firm significantly rises by 19 percent if the firm is formerly domestic and starts to import at time t. If the firm is formerly domestic and starts to export at time $t$, we observe an increase in the productivity of the firms during the period in question, however PSM-DID estimates suggest that this increase in the productivity of the firm is not significant. From the PSM results in the previous part, we show that only-exporting does not improve TFP of the firms, while starting to export improves LP two periods after the firm starts exporting. Hence insignificant PSM-DID estimates are not surprising for the firms that are formerly domestic and become exporters at time t. When we eliminate the unobserved time invariant effects, one can infer that TFP raises by 10 percentage points between $t-1$ and $t+1$, where the firms that are formerly only importers start to export. The improvement in LP is even stronger and more significant. Finally, our results suggest that if exporter firms start to import both the TFP and LP of the firm raises by 29 and 32 percentage respectively during the period in question. Therefore, we can conclude that engaging in two-way trading activity is a significant channel in improving firm productivity. We note that PSM-DID estimates also suggest importing has a more significant impact on the productivity of the firms than that of exporting.

\footnotetext{
${ }^{22}$ Firm heterogeneity entered the empirical literature with evidence on two way trading activities as well. The general finding of this recently developed empirical literature is that two-way trading improves firm productivity more than either only importing, or only exporting. (Vogel and Wagner, 2010; Smeets and Warzynski, 2013)
} 


\section{Robustness Checks}

\section{Different Matching Methods:}

In order to find the average treatment effects of international trading, we implement nearest neighborhood $(\mathrm{NN})$ matching methodology throughout the paper. However, there are three alternative matching methods to NN matching. These are: Stratification Matching, Kernel Matching and Radius Matching (Becker and Ichino, 2002).

The shortcoming of Stratification Matching is that it ignores the observations in some blocks if either treated or control units are not included in those blocks. NN Matching is an alternative for stratification matching since it matches each treated unit with the control unit with the closest propensity score. Hence unlike stratification matching, each treated unit finds a match with NN Matching. The deficiency of NN matching is that two units can be matched although they have very different propensity score. Nevertheless, Kernel Matching and Radius matching overcome this issue. Radius Matching matches each treated unit with control unit such that the propensity scores of control and treated units fall into the same pre-defined neighborhood. This neighborhood preferably is set to be very small. However, as in the Stratification Matching, Radius Matching ignores the observations if they do not fall into the same neighborhood when the pre-defined neighborhood is set to be very small. On the other hand, the quality of the matching improves as the size of the neighborhood decreases. Lastly, 
Kernel Matching matches all treated units with a weighted average of all control units such that the controls' weights are inversely proportional to the distance between the propensity scores of the two units. All of the matching techniques have both advantages and disadvantages over the others. Hence, none of them is superior to each other (Becker and Ichino, 2002).

Since matching procedures differs from each other and each of them has advantages over the others, in order to have more robust results, we also apply the alternative matching techniques. The PSM-DID estimates of alternative matching techniques are presented in Table 4. The results are consistent with the NN matching algorithm. The only difference is that with stratification matching, the average treatment effect of importing on difference in pre-treatment and post-treatment TFPs of firms is found to be significant at 10 percent level while, the other matching methodologies suggest that importing has no effect on the difference between the pre-treatment and post-treatment TFPs of import-starter firms.

\section{New Cohort Definition:}

As a robustness check, we change our cohort definition as follows: Our treatment group consists of firms which does not import (export) at time t-2 and t-1, starts onlyimporting (only-exporting) at time $\mathrm{t}$ and continues only-importing (only-exporting) at time $t+1$ and $t+2$, whereas our control group includes firms that never import (export) over the sample period (i.e. domestic firms). For two way traders, our treatment group consists of firms which were only-importing (only-exporting) at time $\mathrm{t}-1$ and $\mathrm{t}-2$, starts to export (import) at time $\mathrm{t}$ and continues both importing and exporting at time $\mathrm{t}+1$ and $\mathrm{t}+2$. Our control group includes the firms which remain to be only-importers (only-exporters) over the analysis period. 
By defining the cohorts in this manner, we end up with 4 cohorts. With this new cohort definition, we are able to see how international trade affects the firms who do not export (import) (for the second model only export (only import)) over a longer time horizon and who continues to be importer (exporter) (for the second model two-way trader) for a longer time horizon. By widening the time horizon of post-treatment period, we are able to see how strong is the sustainability of positive effects of international trade on the productivity of the firms. We believe that this new cohort analysis adds more convincing power to our primary findings. Table 5 presents PSM-DID estimation results of new cohort definition with four various matching methodologies. Our previous findings do not change: Importing have greater impact on productivity of firms than exporting. With this new cohort definition, we observe that only importing has positive and significant effect on the difference between the TFPs of posttreatment and pre-treatment period when NN and Stratification Matching algorithms are applied. The effect is still found to be significant when Kernel and Radius matching techniques are applied. This time, we find that exporting has a positively significant effect on the difference between the LPs of post-treatment and pre-treatment periods. The same effect on TFP difference is still insignificant. Further, our results suggest that when exporter firms start to import and continue importing for two consecutive periods, the average treatment effect of two-way trade is found to be insignificant on TFP of the firms when NN and Stratification matching techniques are constructed. Moreover, the significance of ATTs reduces to 0.10 . This result can be attributed to the fact that the size of our treatment group for two-way traders are too small (the number of exporters who did not import at time t-1 and t-2, start to import at time $t$, and continue importing at time $t+1$ and $t+2$ amounts to 12 ).

\section{Conclusion}


Recent studies have shown that international trade is an important means of productivity improvement which is a key element for sustainable growth in the least developed and developing regions of the world. In this paper, for an emerging economy, Turkey, we investigate the impact of international trading activities on firms' productivity gains. Namely, we try to shed light on learning by exporting and learning by importing effects over the period 2003-2010. We apply the PSM algorithm together with DID methodology to the largest and most recent firm level panel available for Turkish manufacturing industry. By making use of the PSM-DID methodology our objective is to accurately identify the productivity gains that arise from learning externalities associated to international trade.

We differentiate between one-way and two-way trading activities in investigating the productivity gains from international trade. Namely, we mean to explore all the different effects of exporting vs. importing by particularly forming treatment groups which include firms that are formerly only importers (only exporters) and become two-way traders afterwards, whereas our control groups include the firms which remain to be only importers (only exporters) over the sample period.

Our results provide robust evidence that both exporting and importing activities do statistically improve productivity of firms, with importing activities being found to have a greater impact on firms' productivity gains than export activities. Our estimated treatment effects show that international trade seems to have a greater impact on LP than on TFP of firms. We also find that compared to one-way trade, two-way trade seems to have a greater positive effect on firms' productivity gains. Finally, the comparison of the effects of two-way trading and one-way trading activities on firm productivity strengthens our findings on the fact that the impact of importing on productivity is greater than that of exporting.

\section{References}


Acharya, R. C., and W. Keller (2009) “Technology Transfer through Imports." Canadian Journal of Economics, 42 (4): 1411-1448.

Albornoz, F., and M. Ercolani, (2007) "Learning by Exporting: Do Firm Characteristics Matter? Evidence from Argentinian Panel Data." Department Of Economics Discussion Paper-University of Birmingham 17.

Aldan, A., and M. Günay (2008) "Entry to Export Markets and Productivity: Analysis of Matched Firms in Turkey." The Central Bank of the Republic of Turkey, Working Paper 08/05.

Arnold, J. M. (2005) "Productivity Estimation at the Plant Level: A Practical Guide." Unpublished manuscript 27.

Arnold, J. M., and K. Hussinger (2005) "Export Behavior and Firm Productivity in German Manufacturing: A Firm-Level Analysis.” Review of World Economics, 141 (2): 219-243.

Aw, B-Y., and A. R. Hwang (1995) "Productivity and the Export Market: A firm-level Analysis.” Journal of Development Economics, 47(2): 313-332.

Aw, B.Y., S. Chung and M. J. Roberts (2000), "Productivity and Turnover in the Export Market: Micro-level Evidence from the Republic of Korea and Taiwan (China)." The World Bank Economic Review, 14(1):65-90. 
Bas, M., and V. Strauss-Kahn (2010) "Does Importing More Inputs Raise Exports?: Firm Level Evidence from France.” MPRA Paper No. 27315, December.

Baldwin, J.R. and W. Gu. (2004) "Trade Liberalization: Export-Market Participation, Productivity Growth and Innovation.” Oxford Review of Economic Policy, 20(3): 372-392.

Becker, S. O., and A. Ichino (2002) "Estimation of Average Treatment Effects Based on Propensity Scores.” The Stata Journal, 2(4): 358-377.

Bernard, A. B., and J. B. Jansen (1999) "Exceptional Exporter Performance: Cause, Effect or both?." Journal of International Economics, 47(1): 1-25.

Bernard, A.B., and J. Wagner (2001) "Export Entry and Exit by German Firms." Review of World Economics, 137(1): 105-123.

Bernard, A.B., J.B. Jensen, and P.K. Schott (2006) "Trade Costs, Firms and Productivity.” Journal of Monetary Economics, 53 (5): 917-937.

Blundell, R., and M.C. Dias (2000) "Evaluation Methods for Non-Experimental Data.” Fiscal Studies, 21(4): 427-468.

Castellani, D. (2002) "Export Behavior and Productivity Growth: Evidence from Italian Manufacturing Firms.” Weltwirtschaftliches Archiv, 138(4): 605-628. 
Clerides, S.K., S. Lach, and J.R. Tybout (1998) “Is Learning by Exporting Important? MicroDynamic Evidence from Colombia, Mexico, and Morocco." The Quarterly Journal of Economics, 113 (3): 903-947.

Coe, D. T., and E. Helpman (1995) “International R\&D Spillovers." European Economic Review, 39(5): 859-887.

De Loecker, J. (2007) "Do Exports Generate Higher Productivity? Evidence from Slovenia." Journal of International Economics, 73(1): 69-98.

Dehejia, H. R., and S. Wahba (2002) "Propensity Score Matching Methods for Non-Experimental Causal Studies.” Review of Economics and Statistics, 84(1): 151161.

Eaton, J., and S. Kortum (2001) "Technology, Trade, and Growth: A Unified Framework.” European Economic Review, 45(4): 742-755.

Forlani, E. (2010) “Irish Firms' Productivity and Imported Inputs." CORE Discussion Paper 2010/15, April.

Girma, S., A. Greenaway, and R. Kneller. (2004) "Does Exporting Increase Productivity?: A Microeconometric Analysis of Matched Firms." Review of International Economics, 12(5): 855-866.

Greenaway, D., and R. Kneller (2007) "Firm Heterogeneity, Exporting and Foreign Direct Investment." The Economic Journal, 117 (517): 134-161. 
Griliches, Z. and J. Mairesse (1995), Production Functions: the Search for Identification, National Bureau of Economic Research. No. w5067.

Grossman, G.M., and E. Helpman (1991) "Trade, Knowledge Spillovers, and Growth.” European Economic Review, 35(2): 517-526.

Hall, B.H., and J. Mairesse (1995) "Exploring The Relationship Between R\&D and Productivity in French Manufacturing Firms.” Journal of Econometrics, 65(1): 263-293.

Halpern, L., Koren M., A., Szeidl (2005) “Imports and Productivity", Institute of Economics, Hungarian Academy of Sciences, mimeo, June.

Isgut, A. (2001). "What's Different about Exporters?: Evidence from Colombian Manufacturing.” Journal of Development Studies, 37(5): 57-82.

Isgut, A., and A. Fernandes. (2007) "Learning-by-Exporting Effects: Are They For Real?" MPRA Working Paper 3121, Munich Personal RePEc Archive, University Library of Munich, Germany.

Kasahara, H., and B. Lapham (2008) "Productivity and the Decision to Import and Export: Theory and Evidence.” CESifo Working Paper 2240, CESifo Group Munich.

Levinsohn, J., and A. Petrin (2003) "Estimating Production Functions Using Inputs to Control for Unobservables.” The Review of Economic Studies, 70(2): 317-341. 
Maggioni, D. (2012) "Learning by Exporting in Turkey: An Investigation for Existence and channels." Global Economy Journal 12 (2): 1-20.

Melitz, M.J. (2003) “The Impact of Trade on Intra-Industry Reallocations and Aggregate Industry Productivity.” Econometrica, 71 (6): 1695-1725.

Olley, G.S. and A. Pakes (1996) "The Dynamics of Productivity in Telecommunications Equipment Industry.” Econometrica, 64 (6): 1263-1297.

Paul, C. J. M., and M. Yasar (2009) “Outsourcing, Productivity, and Input Composition at the Plant Level.” Canadian Journal of Economics, 42 (2): 422-439.

Rivera-Batiz, L.A., and P.M. Romer (1991) "International Trade with Endogenous Technological Change.” European Economic Review, 35(4): 971-1001.

Roberts, M.J., and J. R. Tybout (1997) "The Decision to Export in Colombia: An Empirical Model of Entry with Sunk Costs.” The American Economic Review, 87(4):545-564.

Rosenbaum, P. and D. Rubin (1983) "The Central Role of the Propensity Score in Observational Studies for Causal Effects." Biometrica, 70(1): 41-55.

Sargent, T. C., and E. R. Rodriguez (2000) "Labour or Total Factor Productivity: Do We Need to Choose?" International Productivity Monitor, Centre for the Study of Living Standards,Fall (1): 41-44 
Serti, F., and C. Tomasi (2008) "Self-Selection and Post-Entry Effects of Exports: Evidence from Italian Manufacturing Firms.” Review of World Economics, 144 (4): 660-694.

Silva, A., O. Afonso, and A. P. Africano. "Learning-by-Exporting: What We Know and What We Would Like to Know.” The International Trade Journal, 26 (3): 255-288.

Smeets, V., and F. Warzynski (2013) "Estimating Productivity with Multi-Product Firms, Pricing Heterogeneity and The Role of International Trade." Journal of International Economics, 90(2): 237-244.

Van Biesebrock, J. (2003) "Exporting Raises Productivity in Sub-Saharan African Manufacturing Plants.” National Bureau of Economic Research, No. w10020.

Vogel, A., and J. Wagner (2010) "Higher Productivity in Importing German Manufacturing Firms: Self-selection, Learning from Importing, or Both?" Review of World Economics, 145 (4): 641-665.

Wagner, J. (2007) "Exports and Productivity: A Survey of the Evidence from Firm-Level Data." The World Economy, 30(1): 60-82.

Wagner, J. (2012) “International Trade and Firm Performance: A Survey of Empirical Studies Since 2006." Review of World Economics, 148 (2): 235-267.

Yasar, M. and R. M. Rejesus (2005) "Exporting Status and Firm Performance: Evidence from A matched sample." Economics Letters, 88(3): 397-402. 
Yasar, M., P.Garcia, C.H. Nelson and R.M.Rejesus (2007) "Is there Evidence of Learning-by-Exporting in Turkish Manufacturing Industries?" International Review of Applied Economics, 21(2): 293-305.

Yasar, M. and C.J.M. Paul (2008) "Foreign Technology Transfer and Productivity: Evidence From a Matched Sample.” Journal of Business and Economic Statistics, 26(1):105-112.

Yılmaz, K. and Özler, Ş. (2005) "Foreign Direct Investment and Productivity Spillovers: Identifying Linkages through Product-based Measures," Unpublished manuscript, December 2005. 


\section{Appendix}

Tables

Table 1. Comparison of Treatment and Control Groups: Matched vs. Unmatched

\begin{tabular}{|c|c|c|c|c|c|c|}
\hline \multicolumn{7}{|c|}{ Panel A } \\
\hline \multicolumn{7}{|c|}{$\begin{array}{l}\text { Treatment Group: Importers } \\
\text { Control Group: Domestic Firms }\end{array}$} \\
\hline \multirow[b]{2}{*}{ (Lagged values) } & \multicolumn{3}{|c|}{ Matched Sample } & \multicolumn{3}{|c|}{ Unmatched Sample } \\
\hline & Only Import & Domestic & $\begin{array}{l}\text { T-Test for the } \\
\text { Mean } \\
\text { Differences }\end{array}$ & Only Import & Domestic & $\begin{array}{l}\text { T-Test for the } \\
\text { Mean } \\
\text { Differences }\end{array}$ \\
\hline TFP & 7.38 & 7.48 & -6.2 & 7.38 & 7.06 & 19.6 \\
\hline LP & 9.83 & 9.77 & 0.64 & 9.83 & 9.41 & 7.08 \\
\hline WAGE_L & 8.59 & 8.60 & -0.44 & 8.59 & 8.54 & 3.85 \\
\hline EMPLOYEE & 4.02 & 4.00 & 0.55 & 3.90 & 3.72 & 10.98 \\
\hline CAPINT & 10.54 & 10.59 & -0.72 & 10.54 & 10.03 & 11.42 \\
\hline ULC & 0.11 & 0.12 & -0.63 & 0.12 & 0.21 & -9.07 \\
\hline SECO & $2.9 \mathrm{e}+09$ & $2.8 \mathrm{e}+09$ & 0.65 & $2.6 e+09$ & $2.7 e+09$ & -0.35 \\
\hline Sample Size & 214 & 214 & & 544 & 21937 & \\
\hline
\end{tabular}

\section{Treatment Group: Exporters}

Control Group: Domestic Firms

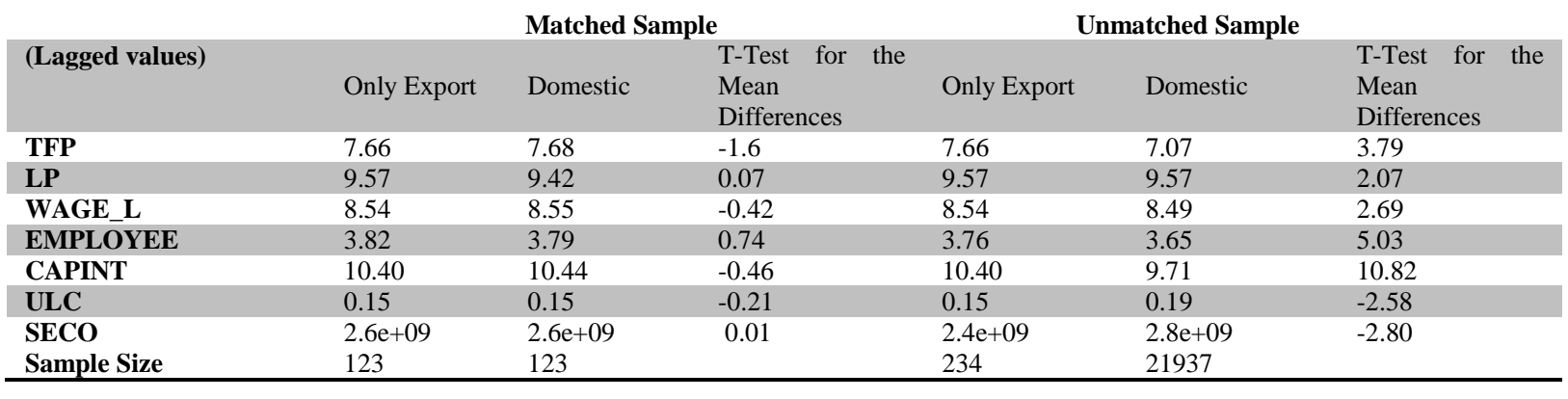

\section{Panel C}

\section{Treatment Group: Two-Way Traders}

Control Group: Only Importers

\begin{tabular}{|c|c|c|c|c|c|c|}
\hline \multirow[b]{2}{*}{ (Lagged values) } & \multicolumn{3}{|c|}{ Matched Sample } & \multicolumn{3}{|c|}{ Unmatched Sample } \\
\hline & $\begin{array}{l}\text { Two-way } \\
\text { Trader }\end{array}$ & Only Import & $\begin{array}{l}\text { T-Test for the } \\
\text { Mean } \\
\text { Differences }\end{array}$ & $\begin{array}{l}\text { Two-Way } \\
\text { Trader }\end{array}$ & Only Import & $\begin{array}{l}\text { T-Test for the } \\
\text { Mean } \\
\text { Differences }\end{array}$ \\
\hline TFP & 7.92 & 8.11 & -1.8 & 7.92 & 7.35 & 7.43 \\
\hline LP & 9.78 & 9.85 & -0.78 & 9.78 & 9.50 & 4.03 \\
\hline WAGE_L & 8.59 & 8.57 & 1.14 & 8.59 & 8.54 & 3.85 \\
\hline EMPLOYEE & 4.30 & 4.34 & -0.82 & 4.30 & 3.92 & 11.51 \\
\hline CAPINT & 10.85 & 10.67 & 1.8 & 10.85 & 10.68 & 2.37 \\
\hline ULC & 0.09 & 0.10 & -1.16 & 0.09 & 0.11 & -2.77 \\
\hline SECO & $3.0 \mathrm{e}+09$ & $3.0 \mathrm{e}+09$ & 0.05 & $3.0 \mathrm{e}+09$ & $2.7 e+09$ & 2.23 \\
\hline Sample Size & 556 & 556 & & 885 & 28829 & \\
\hline
\end{tabular}

\section{Panel D}

\section{Treatment Group: Two-Way Traders}

Control Group: Only Exporters

\begin{tabular}{|c|c|c|c|c|c|c|}
\hline \multirow[b]{2}{*}{ (Lagged values) } & \multicolumn{3}{|c|}{ Matched Sample } & \multicolumn{3}{|c|}{ Unmatched Sample } \\
\hline & $\begin{array}{l}\text { Two-way } \\
\text { Trader }\end{array}$ & Only Export & $\begin{array}{l}\text { T-Test for the } \\
\text { Mean } \\
\text { Differences }\end{array}$ & $\begin{array}{l}\text { Two-Way } \\
\text { Trader }\end{array}$ & Only Export & $\begin{array}{l}\text { T-Test for the } \\
\text { Mean } \\
\text { Differences }\end{array}$ \\
\hline TFP & 7.53 & 7.75 & -1.04 & 7.53 & 7.42 & 0.69 \\
\hline LP & 9.78 & 9.85 & -0.68 & 9.78 & 9.50 & 4.03 \\
\hline Ln(WAGE_L) & 8.54 & 8.53 & 0.69 & 8.54 & 8.49 & 2.69 \\
\hline Ln(EMPLOYEE) & 3.87 & 3.89 & -0.25 & 3.87 & 3.72 & 3.16 \\
\hline CAPINT & 10.66 & 10.62 & 0.23 & 10.66 & 9.92 & 5.17 \\
\hline ULC & 0.11 & 0.12 & -0.84 & 0.11 & 0.15 & -4.15 \\
\hline SECO & $2.5 e+09$ & $2.8 \mathrm{e}+09$ & -0.99 & $2.5 e+09$ & $2.8 \mathrm{e}+09$ & 0.41 \\
\hline Sample Size & 116 & 116 & & 133 & 3204 & \\
\hline
\end{tabular}


Table 2. Average Treatment Effects of Importing and Exporting on Productivity of Firms:

\begin{tabular}{|c|c|c|c|c|c|c|}
\hline \multicolumn{7}{|c|}{ PSM Estimates } \\
\hline $\begin{array}{l}\text { ATT } \\
\text { (Domestic } \\
\text { Firms Start to } \\
\text { Import) }\end{array}$ & $\begin{array}{l}\mathrm{TFP}_{\mathrm{t}} \\
0.18 \\
(0.17)\end{array}$ & $\begin{array}{l}\mathrm{TFP}_{\mathrm{t}+1} \\
0.36^{* *} \\
(0.18)\end{array}$ & \begin{tabular}{l}
\multicolumn{1}{c}{$\mathrm{TFP}_{\mathrm{t}+2}$} \\
$0.36^{* *}$ \\
$(0.18)$
\end{tabular} & $\begin{array}{l}\mathrm{LP}_{\mathrm{t}} \\
0.23 * * * \\
(0.08)\end{array}$ & $\begin{array}{l}\mathrm{LP}_{\mathrm{t}+1} \\
0.28 * * * \\
(0.08)\end{array}$ & $\begin{array}{l}\mathrm{LP}_{\mathrm{t}+2} \\
0.24 * * * \\
(0.09)\end{array}$ \\
\hline $\begin{array}{l}\text { ATT } \\
\text { (Domestic } \\
\text { Firms Start to } \\
\text { Export) }\end{array}$ & $\begin{array}{l}-0.22 \\
(0.22)\end{array}$ & $\begin{array}{l}0.11 \\
(0.24)\end{array}$ & $\begin{array}{l}0.11 \\
(0.24)\end{array}$ & $\begin{array}{l}0.11 \\
(0.08)\end{array}$ & $\begin{array}{l}0.05 \\
(0.10)\end{array}$ & $\begin{array}{l}0.23 * * * \\
(0.11)\end{array}$ \\
\hline $\begin{array}{l}\text { ATT } \\
\text { (Importer } \\
\text { Firms Start to } \\
\text { Export) }\end{array}$ & $\begin{array}{l}0.004 \\
(0.11)\end{array}$ & $\begin{array}{l}0.11 \\
(0.11)\end{array}$ & $\begin{array}{l}0.11 \\
(0.11)\end{array}$ & $\begin{array}{l}0.12 * * * \\
(0.05)\end{array}$ & $\begin{array}{l}0.19 * * * \\
(0.06)\end{array}$ & $\begin{array}{l}0.15^{* * *} \\
(0.06)\end{array}$ \\
\hline $\begin{array}{l}\text { ATT } \\
\text { (Exporter } \\
\text { Firms Start to } \\
\text { Import) }\end{array}$ & $\begin{array}{l}0.49 * * \\
(0.25)\end{array}$ & $\begin{array}{l}0.67 * * * \\
(0.25)\end{array}$ & $\begin{array}{l}0.67 * * * \\
(0.25)\end{array}$ & $\begin{array}{l}0.36 * * * \\
(0.12)\end{array}$ & $\begin{array}{l}0.37 * * * \\
(0.10)\end{array}$ & $\begin{array}{l}0.32 * * \\
(0.16)\end{array}$ \\
\hline
\end{tabular}

Notes: (1) Standard Errors are shown in parenthesis.

(2) $* * *, * *, *$ indicates statistical significance at $1 \%, 5 \%$ and $10 \%$ respectively.

Table 3. PSM-DID Estimates

\begin{tabular}{|c|c|c|c|c|}
\hline \multicolumn{5}{|c|}{ Average Treatment Effects From PSM-DID Estimates } \\
\hline & $\begin{array}{l}\text { ATT } \\
\text { (Domestic Firms } \\
\text { Start to Import) }\end{array}$ & $\begin{array}{l}\text { ATT (Domestic } \\
\text { Firms Start to } \\
\text { Export) }\end{array}$ & $\begin{array}{l}\text { ATT (Importer } \\
\text { Firms Start to } \\
\text { Export) }\end{array}$ & $\begin{array}{l}\text { ATT } \\
\text { (Exporter } \\
\text { Firms Start to } \\
\text { Import) }\end{array}$ \\
\hline $\begin{array}{l}\text { Outcome: } \\
\text { TFP }_{\mathrm{t}+1}-\text { TFP }_{\mathrm{t}-1}\end{array}$ & $\begin{array}{l}0.09 \\
(0.09)\end{array}$ & $\begin{array}{l}0.02 \\
(0.11)\end{array}$ & $\begin{array}{l}0.10^{*} \\
(0.06)\end{array}$ & $\begin{array}{l}0.29 * * * \\
(0.14)\end{array}$ \\
\hline $\begin{array}{l}\text { Outcome: } \\
\mathbf{L P}_{\mathrm{t}+\mathbf{1}}-\mathbf{L P}_{\mathrm{t}-\mathbf{1}}\end{array}$ & $\begin{array}{l}0.19 * * * \\
(0.07)\end{array}$ & $\begin{array}{l}0.02 \\
(0.09) \\
\end{array}$ & $\begin{array}{l}0.13 * * * \\
(0.04)\end{array}$ & $\begin{array}{l}0.32 * * * \\
(0.12)\end{array}$ \\
\hline
\end{tabular}

Notes: (1) Standard Errors are shown in parenthesis.

(2) $* * *, * *, *$ indicates statistical significance at $1 \%, 5 \%$ and $10 \%$ respectively. 
Table 4. PSM-DID Estimate Results with different matching techniques

\begin{tabular}{lcccc}
\hline \multicolumn{5}{c}{ Average Treatment Effects From PSM-DID Estimates } \\
\hline & \multicolumn{5}{c}{ Stratification Results } \\
Outcome: & $0.12^{*}$ & 0.07 & $0.12^{* * *}$ & $0.18^{*}$ \\
TFP $_{\mathbf{t}+\mathbf{1}^{-} \mathbf{T F P}} \mathbf{t}_{\mathbf{1}}$ & $(0.06)$ & $(0.07)$ & $(0.03)$ & $(0.09)$ \\
& $0.10^{* *}$ & 0.03 & $0.08^{* *}$ & $0.15^{* *}$ \\
$\begin{array}{l}\text { Outcome: } \mathbf{L P}_{\mathbf{t}+\mathbf{1}^{-}} \\
\mathbf{L P}_{\mathbf{t}-\mathbf{1}}\end{array}$ & $(0.04)$ & $(0.05)$ & $(0.04)$ & $(0.07)$
\end{tabular}

Kernel Matching Results

$\begin{array}{lllll}\text { Outcome: } & 0.09 & 0.05 & 0.11^{* * *} & 0.17^{*} \\ \mathbf{T F P}_{\mathbf{t}+\mathbf{1}}-\mathbf{T F P}_{\mathbf{t}-\mathbf{1}} & (0.06) & (0.08) & (0.02) & (0.10) \\ \text { Outcome: } & 0.09 * * & 0.004 & 0.08^{* *} & 0.11^{* *} \\ \mathbf{L P}_{\mathbf{t}+\mathbf{1}}-\mathbf{L} \mathbf{P}_{\mathbf{t}-\mathbf{1}} & (0.04) & (0.05) & (0.03) & (0.04)\end{array}$

\begin{tabular}{llcll} 
& \multicolumn{4}{c}{ Radius Matching Results } \\
Outcome: & 0.08 & 0.04 & $0.12^{* * *}$ & $0.18^{*}$ \\
TFP $_{\mathbf{t}+\mathbf{1}^{-}} \mathbf{T F P}_{\mathbf{t}-\mathbf{1}}$ & $(0.06)$ & $(0.08)$ & $(0.02)$ & $(0.10)$ \\
$\begin{array}{l}\text { Outcome: } \mathbf{L P}_{\mathbf{t}+\mathbf{1}^{-}} \\
\mathbf{L P}_{\mathbf{t}-\mathbf{1}}\end{array}$ & $0.10^{* *}$ & 0.003 & $0.09 * *$ & $0.12^{* *}$ \\
& $(0.04)$ & $(0.05)$ & $(0.03)$ & $(0.04)$ \\
\hline
\end{tabular}

Notes: (1) Standard Errors are shown in parenthesis.

(2) $* * *, * *, *$ indicates statistical significance at $1 \%, 5 \%$ and $10 \%$ respectively. 
Table 5. PSM-DID Estimate Results with new cohort definition

\begin{tabular}{|c|c|c|c|c|}
\hline \multicolumn{5}{|c|}{ Average Treatment Effects From PSM-DID Estimates } \\
\hline & $\begin{array}{l}\text { ATT } \\
\text { (Domestic } \\
\text { Firms Start to } \\
\text { Import) }\end{array}$ & $\begin{array}{l}\text { ATT } \\
\text { (Domestic } \\
\text { Firms Start to } \\
\text { Export) }\end{array}$ & $\begin{array}{l}\text { ATT } \\
\text { (Importer } \\
\text { Firms Start to } \\
\text { Export) }\end{array}$ & $\begin{array}{l}\text { ATT } \\
\text { (Exporter } \\
\text { Firms Start to } \\
\text { Import) }\end{array}$ \\
\hline \multicolumn{5}{|c|}{ Nearest Neighborhood Matching Results } \\
\hline Outcome: & $0.35 *$ & 0.04 & $0.26 * * *$ & 0.48 \\
\hline $\mathbf{T F P}_{t+2}-\mathbf{T F P}_{\mathrm{t}-2}$ & $(0.19)$ & $(0.17)$ & $(0.09)$ & $(0.65)$ \\
\hline Outcome: & $0.41 * * *$ & $0.20 *$ & $0.31 * * *$ & 0.29 \\
\hline $\mathbf{L} \mathbf{P}_{t+2}-\mathbf{L} P_{t-2}$ & $(0.13)$ & $(0.11)$ & $(0.10)$ & $(0.75)$ \\
\hline \multicolumn{5}{|c|}{ Stratification Results } \\
\hline $\begin{array}{l}\text { Outcome: } \\
\text { TFP }_{t+2}-\mathbf{T F P}_{t-2}\end{array}$ & $\begin{array}{l}0.26^{*} \\
(0.15)\end{array}$ & $\begin{array}{l}0.09 \\
(0.11)\end{array}$ & $\begin{array}{l}0.25 * * * \\
(0.06)\end{array}$ & $\begin{array}{l}0.16 \\
(0.27)\end{array}$ \\
\hline $\begin{array}{l}\text { Outcome: } \mathbf{L P}_{\mathbf{t}^{-2}} \\
\mathbf{L P}_{\mathrm{t}-2}\end{array}$ & $\begin{array}{l}0.47 * * * \\
(0.08)\end{array}$ & $\begin{array}{l}0.17 * * \\
(0.07)\end{array}$ & $\begin{array}{l}0.25 * * * \\
(0.06)\end{array}$ & $\begin{array}{l}0.28 * \\
(0.16)\end{array}$ \\
\hline
\end{tabular}

Kernel Matching Results

$\begin{array}{lllll}\text { Outcome: } & 0.12 & 0.05 & 0.23 * * * & 0.42 * \\ \mathbf{T F P}_{\mathbf{t}+\mathbf{2}}-\mathbf{T F P}_{\mathbf{t}-\mathbf{2}} & (0.19) & (0.13) & (0.06) & (0.24) \\ \text { Outcome: } & 0.24 * * * & 0.18 * * * & 0.28 * * * & 0.42 * \\ \mathbf{L P}_{\mathbf{t}+\mathbf{2}}-\mathbf{L} \mathbf{P}_{\mathbf{t}-\mathbf{2}} & (0.09) & (0.06) & (0.05) & (0.26)\end{array}$

\begin{tabular}{llcll} 
& \multicolumn{4}{c}{ Radius Matching Results } \\
Outcome: & 0.11 & 0.04 & $0.24 * * *$ & $0.40^{*}$ \\
$\mathbf{T F P}_{\mathbf{t + 2}-\mathbf{T F P}_{\mathbf{t}-2}}$ & $(0.19)$ & $(0.13)$ & $(0.06)$ & $(0.24)$ \\
$\begin{array}{l}\text { Outcome:LPP } \\
\mathbf{L P}_{\mathbf{t}+\mathbf{2}^{-}}\end{array}$ & $0.25^{* * *}$ & $0.17 * *$ & $0.28^{* * *}$ & $0.40^{*}$ \\
& $(0.09)$ & $(0.06)$ & $(0.05)$ & $(0.24)$ \\
\hline
\end{tabular}

Notes:

(1) Standard Errors are shown in parenthesis.

(2) $* * *, * *, *$ indicates statistical significance at $1 \%, 5 \%$ and $10 \%$ respectively. 